\title{
DEVIANCE IN THE ECONOMIC BEHAVIOUR AT THE AGE OF ADOLESCENCE
}

\author{
G. Ungureanu
}

\section{Gabriel Ungureanu}

Psychology Department, Institute of Philosophy and Psychology "C. R-Motru", Romanian Academy, Bucharest, Romania.

*Correspondence: Gabriel Ungureanu, Institute of Philosophy and Psychology "C.R-Motru" Romanian House Academy, 13 Calea 13 Septembrie, Bucharest, Romania

E-mail: gabrielungureanu@hotmail.com

Keywords: behaviour, deviance, economic, adolescence, delinquency

\begin{abstract}
The main cause of poverty is the extended economic crisis, among others due to the irrational closing down of hundreds of companies, plants and its emergenet consequence, namely unemployment. Although poverty cannot be considered a direct cause of juvenile delinquency, it strongly influences the way in which families educate their children and the use of illegitimate methods as "solutions". ". Poverty favours the phenomenon "children of the street”, and in turn this „supplies” the statistics of juvenile delinquency. Delinquency, thefts, prostitution and drugs economically add up to the desire of ignorant youngsters to "handle" and find "solutions" in the current society's incipient state of anomie.
\end{abstract}

\section{Perpetual poverty - favouring condition of juvenile delinquency}

The crisis in Romania is moral, psychological, and economic, also showing the incipience of the anomie phenomenon. Anomie (a nomos $G r$.) is a concept that translates by "lack of norms". This is typical of socially deficient societies, in which revolutions and social crises occur, after which social deviance accentuates and social models become ambiguous. Some teenagers psychologically feel the anomic state as a conflict between their developing personality and legislative landmarks that constrain their conduct, as a denial of the values of education that comes from the adult generation and any kind of norm that disregards their needs for creativity and social assertion. The anomic concept was used by R.K. Merton as well, the famous American sociologist who gives it new meanings. In his opinion, social order is restored when there is a balance between goals to be achieved and the legitimate means to accomplish them. Deviance is precisely the individual's reaction to the discrepancy between circulating and society-valorised goals and the possibility to achieve them (Rădulescu 2002) ${ }^{1}$. Because he develops an interior conflict between the image of aspirations and the limited possibilities, the individual, in order to achieve his goal, also turns to illegal actions, going beyond the normative system. Thus, teenagers and adolescents belonging to under-privileged groups are exposed to the road to delinquency and crime. Starting with 1989, along with the onset of economic life restructuring, Romania experimentally tried a series of reforms that attained social expectations only to a small extent and only for a privileged category. Market economy developed really slow, private investments are far from covering the desperate request for jobs, and the quality of life continuously diminished. The national

\footnotetext{
${ }^{1}$ Banciu Dan., Rădulescu M. Sorin Evoluții ale delincvenței juvenile în România. Cercetare şi prevenire socială. Lumina Lex Publishing House, Bucharest, 2002.
} 
average wage is barely above 150 euro and, as a measure for economic balance it is diminished by $25 \%$. In this situation, poverty became perpetual for most people. The most dangerously affected by the effects of poverty are children, adolescents and teenagers that tend to react pulsionally to these conditions. After the research performed by the Research Institute for the Quality of Life, $40 \%$ of children under 7 years old and 50\% of those aged between 7 and 15 confront with low levels of subsistence. Social categories such as unemployed $60 \%$, peasants $57 \%$, wage earners $30 \%$ and pensioners $25 \%$ are brought to the poverty situation and in some cases even to vital endangering. From an ethnical point of view, the most vulnerable population to poverty is that of the Romani people $32 \%$, followed by Romanians 32\%, Hungarians 30\% and other nationalities 36\%. According to the same evaluations, $50 \%$ of the children aged between 7 and 15 live in poor families. (Rădulescu, Grecu according to Zamfir). ${ }^{2}$ The main cause of poverty is the prolonged economic crisis in part because of the irrational liquidation of hundreds of enterprises and plants and because of the consequent unemployment. Although poverty cannot be considered a direct cause of juvenile delinquency, it majorly influences the way families raise their children and the use of illegitimate methods as "solutions". Poverty favours the "children of the street" phenomenon, and it nurtures the statistics of juvenile delinquency. Delinquency, theft, prostitution and drugs come to compensate the desire of ignorant teenagers to "manage" to find "solutions" in society's incipient state of anomie. M. Cussen (source-Internet.) ${ }^{3}$ suggests a relative list divided into seven categories that unfortunately is frequent not only in the case of adults, but also in that of children or adolescents: a) crime and misdemeanours: murder, theft, rape, juvenile delinquency b) suicide c) drug use with psycho-social implications d) deviant sexual conducts include: prostitution, homosexuality, lesbianism, pornography e) religious deviances f) mental illnesses have also been labelled from the point of view of deviation from social norms g) political extremism h).physical handicaps.

The volume of deviance participation between 2005 and 2010.

\begin{tabular}{|c|r|r|r|r|r|r|}
\hline $\begin{array}{c}\text { Categories } \\
\text { of } \\
\text { participants }\end{array}$ & $\mathbf{2 0 0 5}$ & $\mathbf{2 0 0 6}$ & $\mathbf{2 0 0 7}$ & \multicolumn{1}{|c|}{$\mathbf{2 0 0 8}$} & \multicolumn{1}{|c|}{$\mathbf{2 0 0 9}$} & $\mathbf{2 0 1 0}$ \\
\hline $\begin{array}{c}\text { Minors: } \\
\text { total }\end{array}$ & 15253 & 14783 & 14947 & 13831 & 13134 & 12363 \\
\hline $\begin{array}{c}\text { a. younger } \\
\text { than 14 } \\
\text { years }\end{array}$ & 616 & 491 & 637 & 634 & 660 & 631 \\
\hline $\begin{array}{c}\text { b. } 14-17 \\
\text { years }\end{array}$ & 14637 & 14292 & 14310 & 13197 & 12474 & 11732 \\
\hline $\begin{array}{c}\text { Youngsters } \\
\text { (18-30 } \\
\text { years) }\end{array}$ & 62831 & 67238 & 80727 & 82054 & 84129 & 93506 \\
\hline $\begin{array}{c}\text { No } \\
\text { occupation }\end{array}$ & 79456 & 86727 & 102100 & 100714 & 107174 & 116857 \\
\hline Unemployed & 726 & 683 & 571 & 442 & 950 & 1230 \\
\hline $\begin{array}{c}\text { Detained or } \\
\text { arrested }\end{array}$ & 12838 & 11850 & 11562 & 8221 & 8070 & 8551 \\
\hline
\end{tabular}

Source: General Inspectorate of Romanian Police within the Ministry of Administration and Interior (Statistic Directory 2011)

\footnotetext{
${ }^{2}$ Grecu Florentina.,Rădulescu S., Delincvența juvenilă în societatea contemporană, Lumina Lex Publishing House, Bucharest, 2003, p. 145, 146.

${ }^{3} \mathrm{http}: / /$ www.scribd.com/doc/78435148/Deviant-A consultat la 18.02.2012.

4 http://www.politiaromana.ro/date_statistice_anul_2009.htm consultat la 16.02.2012
} 


\section{Psycho-social factors of juvenile delinquency}

\section{Juvenile delinquency}

Deviant behaviour is a type of individual or group action that deflects from the norms and rules of social system getting in conflict with the social-cultural values and social expectations. The term "juvenile delinquency" comes from the French term "deliquance juvenile" which in turn comes from the Latin construction "delinquere juvenis" that designated the ensemble of deflections and violation of social norms, legally sanctioned and committed by minors. The explanation for juvenile delinquency should start from the concept of social maturing. V. Preda ${ }^{5}$ states that social maturing can be defined as "the individual's capacity to maintain a dynamic balance between his interests and those of society, the delinquent seemingly being an individual insufficiently matured from a social point of view and to present social integration difficulties that get in conflict with the requirements of a certain value-normative system, including with legal norms". The delinquent doesn't manage to harmonize his conduct actively and dynamically with the requirements of interpersonal relations, because of a socializing deficit determined by the disturbance or insufficiency of processes of assimilation of requirements and social-cultural environment and of processes of accommodating to it by acts of conduct acceptable from a social-legal point of view. Thus, delinquency appears as a disorder of social relationships structure of the individual because of the insufficiency of social maturing. The concept "juvenile delinquency" is approached within the larger spectrum of deviance. The concept of deviance is defined as the ensemble of dysfunctional behaviours that threaten the balance of the social system. The deviances are various, relating to misfit phenomena or social disadaptation. Adrian Neculau (Dictionary of psychology, 1997 $)^{6}$ defines deviant behaviour as a situation of deflection from the norms of a group, to which the deviant person breaks the belonging group's system of rules and instructions and contradicts with the opinions, attitudes, goals, aspirations, behaviours, even clothing of the group or collective.

Annual tendency of minors indicted between 1989 and $2000^{7}$

\begin{tabular}{|r|r|r|}
\hline Year & \multicolumn{1}{|c|}{$\begin{array}{c}\text { Number of minors } \\
\text { incriminated. }\end{array}$} & $\begin{array}{c}\text { Percentage of those } \\
\text { convicted. \% }\end{array}$ \\
\hline 1989 & 3810 & 73,2 \\
\hline 1990 & 4554 & 43,5 \\
\hline 1991 & 8520 & 44,4 \\
\hline 1992 & 9210 & 49,8 \\
\hline 1993 & 10141 & 68,4 \\
\hline 1994 & 11658 & 78,2 \\
\hline 1995 & 12611 & 77,6 \\
\hline 1996 & 12439 & 83,4 \\
\hline 1997 & 13674 & 92,9 \\
\hline 1998 & 10918 & 80,8 \\
\hline 1999 & 8231 & 70,5 \\
\hline 2000 & 7322 & 75,0 \\
\hline
\end{tabular}

\footnotetext{
${ }^{5}$ Preda Vasile, Delincvența Juvenilă. O abordare multidisciplinară, "Presa Universitară Clujeană" Publishing House, Cluj-Napoca, 1998, p. 23, 33-34.

${ }^{6}$ Neculau, A., Dicționar de Psihologie, Babel Publishing House, Bucharest, 1997.

${ }^{7}$ http://www.politiaromana.ro/date statistice_anul_2009.htm consultat la 16.02.2012.
} 
Deviant behaviour can be manifested or hidden, latent, can evolve within certain tolerable limits or can exceed these limits of tolerance; it can be accepted by members of the group if it doesn't endanger their existence, or it can be rejected and sanctioned if it encroaches on the life and activity of group members; it presents various degrees and forms of manifestation, from tolerable to criminal ones. Deviant behaviour, as form of social disadaptation, presents various forms of manifestation.

\section{Crimes against property}

Theft. Children and adolescents of different age can be tempted to steal from various reasons: some of them understand that theft is socially sanctioned and they proceed on doing it out of a desire of adventure, others may steal as a reaction to draw attention to physical or emotional abuse they are subject to within the family, but most of them do it because they do not have the necessary social means to obtain the objects legally or by working. The children and teenagers' natural tendency towards brands acknowledged on the market has long become a habit of orientation to objects possessing these indisputable attributes of quality. Thus, objects that are common to middle-class, such as balls, tennis rackets, electronic consoles, perfumes, T-shirts, etc. prove to be inaccessible to under-privileged children. They can but desire these objects, accumulating frustrations that subsequently turn into anger and open violence, as they do not have access to these goods under no circumstances, for a long period of time. Even under the age of 18 two categories of thieves can be distinguished: amateur or occasional thieves that steal an object tempting them at an infantile level, money to buy food or movie tickets and professional thieves that are part of networks specialized in various types of crimes such as breaking an entry or fraud, car theft, arsons, etc.

The new information technologies are also used by children and adolescents with an IQ of 120 and above, that are tempted to commit crimes on the Internet from various reasons. As general profile, these children come from the middle-class, are aged between 14 and 19, are usually introverted and have poor social contact. They mostly relate to those that show the same preoccupation in fields such as informatics, cybernetics, and electronics. Thus the illegal access to various secured networks, serious crimes like industrial espionage, copying and counterfeiting informatics programs can occur (Andreea Fabian, 2007). ${ }^{8}$ The psycho-social causes of this type of behaviour must be sought especially within primary and secondary groups that do not manage to rightfully accomplish socialization of children and adolescents, in conformity with the norms and values of global society. Among family factors implied in the aetiology of juvenile delinquency, we mention: the "cold - indifferent" attitude of the parents, the parents" "tyrannical" attitude, the conflicting atmosphere within the family, disturbances within the family's moral climate and family disorganization. Of course, the influence of family criminogenic factors must be regarded in relation to their multiple interconditionings with extra-family and psycho-individual factors of children and teenagers.

\section{Prostitution}

Etymologically the Latin verb "prostituo" meant the act of public exposure for and before the sale. Above all, these etymological explanations show the mercantile sense and the despicable moral of trafficking human beings. The wherewithal of prostitution is amazing: declaratively, nobody wants to practice the occupation out of pleasure, it's just that money need to be earned for daily subsistence, clearly state in bad faith those involved. However, in time, researchers have statistically shown that the following factors are invoked when it comes to prostitution: a) unemployment, b) low level of wages and difficult working

\footnotetext{
${ }^{8}$ Fabian, Andreea, Aspecte teoretice şi statistice ale devianței şi delincvenței juvenile, Echinox Publishing House, Cluj Napoca, 2007.
} 
conditions, c) adverse educational climate, d) recruitment in the grid through pimps. (Radulescu 1996) ${ }^{9}$. Several studies performed on delinquent children involved in prostitution have proved the following: most of them came from families where alcohol was consumed, delinquent girls and prostitutes came from families with moral deficiency mainly due to the immoral behaviour of parents who tolerated a promiscuous environment. So, the immorality of the family environment immorality first led girls to alcoholism, prostitution and consequently the various serious crimes. Juvenile prostitution is also widespread in Romania, children of the street children providing a real attraction pole for both Romanian paedophiles and foreign ones. V. Preda states that, in terms of socio-affective and moral, the family climate is more predisposing to deviance when the family has cases of alcoholism, immorality and criminal history, favouring children and adolescents to glide down the slope of crime and promiscuity. Given the above-mentioned aspects it can be said that the family - through the behaviour of its members - is a reference framework and serves as an example, a "model" for adolescents and youngsters. Children coming from such families with side-slips of the moral, socio- affective climate and with a conflictual background can easily associate with criminogenic groups.

\section{Addictions}

As it was noticed in social inquiries performed by authorities regarding drug use and drug traffic, it is not just the user that is affected by this behaviour but the family, close friends, community and consequently the entire society as well, by the huge costs it has to pay. Stelian Turlea, the author of the paper "Drug bomb", points out that: "The family also suffers, being deprived of harmony and anguished to witness the destruction of the one they love". The economic factors must also be mentioned: production loss, increased number of accidents, greater absence from work and higher costs for healthcare. The buyer will eventually pay the price, as he will have to purchase inferior goods at higher costs. The taxpayer will pay the price, as his money is necessary for the government's efforts, for public order troops and for treatment and rehabilitation centres, for drug control. To this the financial support that the drug user offers criminal organizations must be mentioned, which benefit from drugs and criminal activities the user often gives himself up to in order to sustain his vice" (Rădulescu according to Stelian Turlea) ${ }^{10}$. Alcohol use in teenagers and adolescents is an everyday reality that reaches mass proportions, in private or in public places, even if merchandising it to people under 18 years old is forbidden. Unfortunately for many adolescents this behaviour leads to addiction and symptoms of chronic alcoholism that occurs along with the series of specific illnesses, job loss, abandoning school, spending personal resources but those of the family on alcohol and later on the hospital or clinical needs. V. Preda states that the social-affective, moral and also the economic climate of the family is more disturbed when in the family there are cases of alcoholism, immorality, and criminal records, favouring the children and adolescents' slide on the slope of delinquency due to the very familiar negative example. Research shows that alcoholism in families of which delinquents come from manifests approximately three times more frequent than in the families of non-delinquents. The immorality of the family environment in which alcohol was used eventually lead to a permissive atmosphere that favoured alcoholism in the case of young females, as well as prostitution and later to other serious crimes in which they get involved.

Video games have been generating a very attractive activity to millions of children, for at least 30 years, an aspect that determined scientific research regarding their effects on their

\footnotetext{
${ }^{9}$ Rădulescu M. Sorin, Sociologia comportamentului sexual deviant, Nemira Pubishing House, Bucharest, 1996.

${ }^{10}$ Rădulescu M. Sorin, Devianță criminalitate şi patologie socială, Lumina Lex Publishing House, Bucharest, 1999, p. 250.
} 
developing personality. The results of these studies proved both their positive effects and the negative ones. When approaching the computer interaction phenomenon, researcher Ana Maria Marhan showed in the paper Psychology of the use of new technologies ${ }^{11}$ that from the beginning the computer user is facing a pressing of motivational paradox: accomplishing a common task - writing a text, sending a message, taking a picture - competes with the objective of understanding the used system and thus the user will self-limit learning the system's possibilities. It is thus noticed that from a behavioural point of view, the "gamer" adolescent also wastes time to score or win games detrimental to understanding the complex functions of the computer that brings real benefits and possible professional qualifications.

In his turn, Alexandru Tarasov highlights in his paper The psychology of Video Games $^{12}$ the dynamics of relationship psychic mechanisms that are initiated during the games, as well as the effects on conduct. Quoting Donglas Gentile and Craig Anderson, the author states that video games have a greater social influence than media on the aggression phenomenon because of the following factors: a) games are more attractive and interactive. $b$ ) games consolidate aggressive behaviours. c) children imitate these behaviours with every game they play.

Table of definitive or alternative sentences, minors 2005-2010

\begin{tabular}{|c|c|c|c|c|c|c|}
\hline Years & 2005 & 2006 & 2007 & 2008 & 2009 & 2010 \\
\hline $\begin{array}{l}\text { Total number of minors } \\
\text { convicted: }\end{array}$ & 6796 & 6145 & 5019 & 3624 & 3035 & 3263 \\
\hline Fine & 237 & 269 & 192 & 117 & 61 & 88 \\
\hline $\begin{array}{l}\text { Execution of } \\
\text { punishment at work }\end{array}$ & 83 & - & - & - & - & - \\
\hline Jail & 1860 & 1638 & 1369 & 921 & 783 & 821 \\
\hline $\begin{array}{l}\text { Imprisonment with } \\
\text { conditional suspension } \\
\text { of execution of } \\
\text { punishment. }\end{array}$ & 2610 & 2429 & 2071 & 1676 & 1474 & 1582 \\
\hline $\begin{array}{l}\text { Suspension of the } \\
\text { sentence execution } \\
\text { under supervision }\end{array}$ & 511 & 462 & 472 & 289 & 257 & 362 \\
\hline Educative measures & 1495 & 1347 & 915 & 621 & 460 & 410 \\
\hline Reprimand & 491 & 436 & 310 & 196 & 145 & 139 \\
\hline On parole. & 702 & 557 & 349 & 205 & 157 & 140 \\
\hline $\begin{array}{l}\text { Internment in an re- } \\
\text { educative centre }\end{array}$ & 298 & 344 & 252 & 217 & 154 & 128 \\
\hline $\begin{array}{l}\text { Internment in an } \\
\text { educative medical } \\
\text { centre }\end{array}$ & 4 & 10 & 4 & 3 & 4 & 3 \\
\hline
\end{tabular}

Source: Romania's statistic directory $2011^{13}$

As far back as 1993, video games classification was imposed as follows: "E (everyone) $\mathrm{T}$ (teen) young (Y) and $\mathrm{M}$-mature, this aspect leading to the limitation of the access of children to games inappropriate to their age. Thus in 2003 Entertainment Software

\footnotetext{
${ }^{11}$ Marhan, Ana-Maria, Psihologia Utilizării Noilor Tehnologii, Institutul European Publishing House, Iaşi, 2007.

12 Tarasov, A., Psihologia jocurilor video, Lumen Publishing House, Iaşi, 2007.

${ }^{13}$ Anuarul Statistic al României 2011
} 
Rating Board presented a significantly improved classification starting with the age of three up to adults over 18 years old.

Although research in the scope of this phenomenon is few, one can still state that the policies quickly applied in the EU as a consequence of scientific proofs, significantly reduced the rate of aggressive behaviour triggered by video games.

\section{Conclusion}

Deviance is a complex and multidimensional phenomenon that has always existed in our country as well because of dysfunctions in approaching the reality of social life. Structural-organizational mistakes of the past generation are also passed down and implemented to "adaptive" behaviours learnt by the young generation, in a developing pressing. Adolescents already notice educational slips and cannot easily break from perished value and concept traditions, triangulated in the family, received or adopted at psychological level. Moreover, the formal-educational component of the current social system no longer has the ability to motivate the new generation to build a professional career, not to mention satisfaction of a job fairly paid. This is how the main negative justification of juvenile delinquents is initiated, who firstly presents itself as being an economic issue. Paradoxically the answer of our society regarding the integration of teenagers is also negative, of limitativeselective refusal, and that proves above all the economic incapacity to sustain, socialize with and integrate the under-privileged groups. Economic and organizational incapacity of vulnerable groups is mirrored at the level of common sense in negative statistics of deviance and delinquency in progress. We can also say that deviance of teenagers represents the sum of yesterday's educational mistakes associated with today's anomic incipience.

\section{Bibliography}

Anuarul Statistic al României, 2011;

Doina Ştefana Săucan, Aurora Liiceanu, Mihai I. Micle, Încălcarea legii ca stil

de viață. Vulnerabilitatea adolescenților la criminalitate, "Editura Academiei Bucureşti” Publishing House, Bucharest, 2009;

Tarasov, A., Psihologia jocurilor video, Lumen Publishing House, Iaşi, 2007;

Marhan, Ana-Maria, Psihologia Utilizării Noilor Tehnologii, Institutul European Publishing House, Iaşi, 2007;

Fabian, Andreea, Aspecte teoretice şi statistice ale devianţei şi delincvenței juvenile Echinox Publishing House, Cluj Napoca, 2007;

Grecu Florentina.,Rădulescu S., Delincvența juvenilă în societatea contemporană, Lumina Lex Publishing House, Bucharest, 2003;

Octavian Pop, Aspecte criminologice privind delincvența juvenilă în perioada de tranziție a României, MIRTON Publishing House, Bucharest, 2003;

Banciu Dan., Rădulescu M. Sorin, Evoluții ale delincvenței juvenile în România.

Cercetare şi prevenire socială, Lumina Lex Publishing House, Bucharest, 2002;

Rădulescu M. Sorin, Devianță criminalitate şi patologie socială, Lumina Lex

Publishing House, Bucharest, 1999;

Preda Vasile, Delincvența Juvenilă. O abordare multidisciplinară, "Presa Universitară Clujeană” Publishing House, Cluj-Napoca, 1998;

Neculau, A., Dicționar de Psihologie, Babel Publishing House, Bucharest, 1997;

Rădulescu Adrian, Psihologia delincventului minor, ANDO TOURS Publishing

House, Timişoara, 1996;

Rădulescu M. Sorin, Sociologia comportamentului sexual deviant, Nemira

Publishing House, Bucharest, 1996;

Turlea, S., Bomba Drogurilor, Humanitas Publihing House, Bucharest, 1991. 
Internet sourses:

http://www.scribd.com/doc/78435148/Deviant-A consultat la 18.02.2012

http://www.politiaromana.ro/date_statistice_anul_2009.htm consultat la 16.02.2012

http://www.21stcenturysciencetech.com/articles/New_violence.htmlconsultat la16.02.2012

http://www.referat.ro/referate_despre/despre_criminologie.html consultat la 19.02.2012. 